\title{
A Study on Outcome of Myringoplasty
}

\author{
Md. Mizanur Rahman ${ }^{1}$, Md. Mozharul Islam², Md. Hasan Zafar ${ }^{3}$, Md. Manjur Rahim ${ }^{4}$, Md. Shahjad \\ Selim ${ }^{5}$, Md. Khalid Asad ${ }^{6}$
}

\begin{abstract}
A cross sectional study was carried out from July 2004 to June 2006 at the department of ENT of SSMC and Mitford Hospital, Dhaka with the aim to assess the graft take rate as well as hearing improvement. This study included 60 patients those underwent myringoplasty operations by underlay technique with temporalis fascia graft. The age range of patients was 15-45 years. In this study graft take rate was $86.67 \%$ after 2 months. There was no gross difference in graft take in respect of sex. The pre operative and post operative hearing threshold is statistically significant which indicates improvement of hearing. Therefore, myringoplasty is a valid treatment modality for closing perforation of tympanic membrane, prevention of infection and improvement of hearing.
\end{abstract}

Keywords: Myringoplasty, hearing threshold, underlay technique.

1. Senior Consultant, Department of ENT \& Head Neck Surgery, 100 Bedded Sadar Hospital, Shariatpur.

2. Associate Professor, Dept of ENT. Kushtia Medical College. Kushtia.

3. Assistant Professor, Dept of ENT .Cox's Bazar Medical College, Cox's Bazar.

4. Assistant Professor, Dept. of ENT. Kushtia Medical College. Kushtia.

5. Assistant Professor, Dept. of ENT. Kushtia Medical College. Kushtia.

6. Assistant Professor, Dept. of ENT. Shaheed Syed Nazrul Islam Medical College, Kishorganj.

Address of correspondence: Dr. Md. Mizanur Rahman, Senior Consultant, Department of ENT \& Head Neck Surgery, 100 Bedded Sadar Hospital, Shariatpur. E-mail: dr.mizanur.63@gmail.com

\section{Introduction}

In Bangladesh the incidence of Chronic Suppurative Otitis Media (CSOM) is very high because of poor socio-economic condition, overcrowding, poor nutrition and lack of health education. ${ }^{1}$

Among the two type of chronic suppurative otitis media (tubotympanic and attico-antral variety) tubotympanic variety is the commonest and is called safe as the risk of complication are less. ${ }^{2}$ The name tubotympanic indicates disease is limited to Eustachian Tube and tympanic cavity and is always characterized by perforation in the tympanic membrane.
Hearing loss occurring from chronic suppurative otitis media is a burden to the individual and also to the family and entire society. The predominant hearing loss in tubotympanic disease is conductive in nature. There is a significant quantitative correlation between the size and the site of perforation and hearing loss. Small perforation ( $10 \%$ of the membrane) produce losses of $10-15 \mathrm{~dB}$ below $3 \mathrm{KHz}$. Large perforation produce severe hearing losses over the whole range particularly at higher frequencies, through these perforations the sound waves acts directly on the round and oval windows. 
Myringoplasty is the operation specifically designed to repair or reconstruct the tympanic membrane. A successful myringoplasty controls recurrent infection, improves hearing, prevents tympanosclerosis and cochlear degeneration and hearing aid use. Myringoplasty has been suggested to protect the middle ear by preventing the progression of ossicular pathology and preventing choleasteatoma formation. ${ }^{3}$

The pre-requisites of myringoplasty are dry central perforation of tympanic membrane in CSOM, free from any pathological lesion in the external ear, middle ear and mastoid, functioning Eustachian tube and no systemic diseases like diabetes mellitus, hypertension etc.

At present, myringoplasty is a common in the otolaryngology department having microsurgical facilities. The present study aims at evaluating the surgical results of myringoplasty in selected patients with tympanic membrane perforation and assessing the factors potentially influencing their outcome.

\section{Aims and Objectives}

1. To asses the graft taking rate after myringoplasty.

2. To asses the hearing status after surgery.

\section{Methods}

This was a cross sectional experiment type of study and carried out in the department of Otolaryngology and Head-Neck Surgery, Sir Salimullah Medical College and Mitford Hospital, Dhaka from July 2004 to June 2006.

Purposive sampling from all consecutive patients of chronic suppurative otitis media (tubo-tympanic variety) admitted in ENT department of Sir Salimullah Medical College and Mitford Hospital, Dhaka, during the study period were selected for the study as per criteria has been described below. A total number of 60 patients were identified accordingly and were included in this study.

\section{Results}

Table-l:

Distribution of patients according to age and graft take rate $(n=60)$

\begin{tabular}{|c|c|c|c|c|}
\hline Age range (years) & Number of patients & $\begin{array}{c}\text { Percentage of } \\
\text { patients }\end{array}$ & $\begin{array}{c}\text { Number of graft } \\
\text { taken cases }\end{array}$ & $\begin{array}{c}\text { Percentage of } \\
\text { graft taken cases }\end{array}$ \\
\hline $15-20$ & 22 & 36.67 & 19 & 86.36 \\
\hline $21-30$ & 32 & 53.33 & 29 & 90.62 \\
\hline $31-40$ & 4 & 6.67 & 3 & 75.00 \\
\hline $41-45$ & 2 & 3.33 & 1 & 50.00 \\
\hline
\end{tabular}

Table II:

Socio-economic condition of the patients $(n=60)$

\begin{tabular}{|l|c|c|}
\hline Socio-economic condition & Number of patients & Percentage \\
\hline Poor class & 4 & 6.67 \\
\hline Middle class & 48 & 80.00 \\
\hline Upper class & 8 & 13.33 \\
\hline
\end{tabular}

Table III: 
Distribution of patients according to ear involvement and graft take rate $(n=60)$

\begin{tabular}{|l|c|c|c|c|}
\hline Ear involvement & Number of patients & $\begin{array}{c}\text { Percentage of } \\
\text { patients }\end{array}$ & $\begin{array}{c}\text { Number of graft } \\
\text { taken cases }\end{array}$ & $\begin{array}{c}\text { Number of graft } \\
\text { taken cases }\end{array}$ \\
\hline Unilateral & 38 & 63.33 & 33 & 86.84 \\
\hline Bilateral & 22 & 36.67 & 19 & 86.36 \\
\hline
\end{tabular}

Table IV:

Distribution of patients according to size of perforation and graft take rate $(n=60)$

\begin{tabular}{|l|c|c|c|c|}
\hline Size of perforation & $\begin{array}{c}\text { Number of } \\
\text { patients }\end{array}$ & $\begin{array}{c}\text { Percentage of } \\
\text { patients }\end{array}$ & $\begin{array}{c}\text { Number of graft } \\
\text { taken cases }\end{array}$ & $\begin{array}{c}\text { Percentage of } \\
\text { graft taken cases }\end{array}$ \\
\hline Small size perforation & 8 & 13.33 & 8 & 100 \\
\hline Medium size perforation & 37 & 61.67 & 32 & 86.49 \\
\hline Sub total perforation & 15 & 25.00 & 12 & 80.00 \\
\hline
\end{tabular}

Table V:

Distribution of patients according to site of perforation and graft take rate $(n=60)$

\begin{tabular}{|l|c|c|c|c|}
\hline Site of perforation & Number of patients & $\begin{array}{c}\text { Percentage of } \\
\text { patients }\end{array}$ & $\begin{array}{c}\text { Number of graft } \\
\text { taken cases }\end{array}$ & $\begin{array}{c}\text { Percentage of } \\
\text { graft taken cases }\end{array}$ \\
\hline $\begin{array}{l}\text { Posterior (Behind } \\
\text { the umbo) }\end{array}$ & 6 & 10 & 6 & 100 \\
\hline $\begin{array}{l}\text { Central (Around } \\
\text { the umbo) }\end{array}$ & 45 & 75 & 36 & 86.67 \\
\hline $\begin{array}{l}\text { Anterior (In front of } \\
\text { umbo) }\end{array}$ & 9 & 15 & 7 & 77.78 \\
\hline
\end{tabular}

Table VI:

Overall result of operations $(n=60)$

\begin{tabular}{|l|c|c|}
\hline Tympanic membrane & Number of patients & Percentage of patients \\
\hline $\begin{array}{l}\text { Primary take (intact and mobile } \\
\text { tympanic membrane) }\end{array}$ & 52 & 86.67 \\
\hline Graft failure:- & 8 & 13.33 \\
\hline a) Post operative infection & 4 & 6.67 \\
\hline b) Re perforation & 4 & 6.67 \\
\hline
\end{tabular}

Table VII:

Hearing result of operations $(n=60)$

A) Hearing status before and after operations $(n=60)$ 


\begin{tabular}{|c|c|c|}
\hline Number of patients & $\begin{array}{c}\text { Average pre-operative air } \\
\text { conduction threshold }\end{array}$ & $\begin{array}{c}\text { Average post-operative air } \\
\text { conduction threshold }\end{array}$ \\
\hline 22 & $26.80 \mathrm{~dB}$ & $19.10 \mathrm{~dB}$ \\
\hline 32 & $32.40 \mathrm{~dB}$ & $20.30 \mathrm{~dB}$ \\
\hline 04 & $34.50 \mathrm{~dB}$ & $23.80 \mathrm{~dB}$ \\
\hline 02 & $40.50 \mathrm{~dB}$ & $28.70 \mathrm{~dB}$ \\
\hline
\end{tabular}

B) Overall hearing results:

\begin{tabular}{|l|c|}
\hline & Mean dB \\
\hline Pre-operative air conduction threshold & 33.55 \\
\hline Post-operative air conduction threshold & 22.97 \\
\hline Improvement of air conduction threshold & 10.58 \\
\hline
\end{tabular}

C) Distribution of patients according to hearing improvement or not

\begin{tabular}{|l|c|c|}
\hline Hearing improvement or not & Number of patients & Percentage of patients \\
\hline Hearing improvement & 41 & 68.33 \\
\hline No hearing improvement & 19 & 31.67 \\
\hline
\end{tabular}

\section{Discussion}

In this study, age range of patient were from 15 years to 45 years with a mean age of 24 years. Patients age has generally been considered as an influencing factors for surgical outcome. In this study maximum success rate was found within the age group of $21-30$ years $(90.62 \%)$ followed by $15-20$ years. Similar results were observed by Vrabec et al. ${ }^{4}$ In this study the graft take rate was $86.67 \%$ (52 out of 60 ) and the graft failure was $13.33 \%$ (8 out 60 ). The take rate was more than Kotecha et al. ${ }^{5}$ The cause may be due to the fact that the most of the operations were done by experienced hand and there were less infection. The graft take rate was similar to Fisch $(86 \%))^{6,7}$

In this study most of the patient of CSOM had unilateral involvement. In case of bilateral involvement, myringoplasty was done only in one ear in one sitting. Graft take rate was $86.84 \%$ in case of unilateral disease and $86.36 \%$ in case of bilateral disease, a difference that was not statistically significant.

With regard to the role of size of perforation, medium size perforations were the commonest in our study. Success rate was more in case of small $(100 \%)$ and medium size perforation $(86.49 \%)$ than that of subtotal perforations $(80 \%)$. Similar result were also reported by Sade et al. ${ }^{8}$

The site of perforation statistically affect outcome in our series as has previously been reported by others. ${ }^{9,10}$ Central perforations were the commonest. Success rate of posterior perforations $(100 \%)$ are more than central $(86.67 \%)$ and anterior perforations $(77.78 \%)$. Our finding of higher rate of surgical failure in anterior perforation in comparison to posterior perforation, may be due to the more limited vascularization of the anterior part of ear drum and due to limited access to this perforation. ${ }^{11}$

Surgical approach depends on dimension of external auditory canal, site of perforations as well as surgeon option. In this study 
myringoplasty was done through post auricular $(86.67 \%)$ and per meatal (13.33\%) approaches. No significant difference was found between these two approaches which was also found by Kotecha at el. ${ }^{5}$

The mean pre-operative air conduction threshold in the study cases were $33.55 \mathrm{~dB}$. While the mean post-operative air-conduction threshold after two months were $22.97 \mathrm{~dB}$ with a mean audiological improvement of $10.58 \mathrm{~dB}$. The improvement was observed within frequency range of $250-1000 \mathrm{~Hz}$. Post operative hearing was improved in only 41 cases $(68.33 \%)$ and in 19 cases no hearing improvement was found. This hearing gain was more than Doyle at el. ${ }^{12}$ The cause may be due to the fact that our cases had least tympanosclerosis, middle ear scarring or graft thickening. No sensori-neural hearing loss was observed after surgery. In some successful cases, hearing was not improved significantly after surgery despite the tympanic membrane healed perfectly and the middle ear remain aerated. Sheehy and Anderson stated that in most cases of CSOM even though the ossicular chain may appear normal there is some factors of scar tissue around the ossicular chain that prevents total restoration of hearing. ${ }^{13}$

The overall success rate was $86.67 \%$ (52 out of 60 ). Out of 8 graft failure patients, 4 cases due to post operative infection and 4 cases due to re-perforation which were caused by some predisposing factors like chronic tonsillitis, chronic rhino-sinusitis, chronic pharyngitis etc. For statistical analysis of pre operative and post operative hearing threshold, paired ' $\mathrm{t}$ ' test was applied. The ' $p$ ' value of ' $t$ ' test was $<0.01$ which is statistically significant, that means there is a difference between pre operative and post operative hearing threshold which indicates significant improvement of hearing.

\section{References}

1. Amin MN, Choudhury WA, Abdullah M. Pattern of ENT diseases in rural Bangladesh. J Bangladesh College of Physicians and Surgeons, 1989; 7: 2327.
2. Ludman $\mathrm{H}$. Reconstruction of the middle ear. In: Mawson's Diseases of the ear. $6^{\text {th }}$ ed. London. Edward Arnold, 1998: 432-33.

3. Ludman H. Applied Anatomy. In: Mawson's Diseases of the ear. $5^{\text {th }}$ ed. London. Edward Arnold, 1988: 17-25.

4. Vrabec JT, Deskin RW, Grady JJ. Metaanalysis of peadiatric tympanoplasty. Arch Otolaryngolol Head Neck Surg, 1997; 125: 530-34.

5. Kotecha B, Fowler S, Topham J. Myringoplasty: a prospective audit study. Clin Otolaryngol, 1999; 24(2): 126-9.

6. Fisch U. Tympanoplasty, Mastoidectomy and Stapes Surgery. New York. Thieme.1994; pp 194-9.

7. Bhuyian MAH. The result of Myringoplasty. Dissertation. Bangladesh College of Physicians and Surgeons, Mohakhali, Dhaka. 2003.

8. Sade J, Berco E, Brown M. Myringoplasty short and long term results in a training programme. J Larygol Otol, 1981; 95: 653-665.

9. Koch WM, Friedman E, McGill TJI, Healy GB. Tympanoplasty Type I. Arch Otolaryngolol Head Neck Surg, 1990; 116: 35-40.

10. Podoshin L, Fradis M, Malatskey S, David J. Type I Tympanoplasty. Ann J Otol, 1996; 17: 293-6.

11. Denoyelle F, Roger G, Chauvin P, Garabedian EN. Myringoplasty: Preventive factors of outcome. Laryngoscope, 1999; 109: 47-51.

12. Doyle JP, Schleuning AJ, Echevarria J. Tympanoplasty: Should graft be placed medial or lateral to the tympanic 
membrane? Laryngoscope, 1972; 82:

1425-30.
13. Sheehy JJ, Anderson RG. Myringoplasty: Review of 472 cases. Ann Otol Rhynol Laryngol, 1990; 89: 331-334. 